\title{
Effects of bacterial communities on the sensitivity of the phytoplankton Stephanodiscus minutulus and Desmodesmus armatus to tannic acid
}

\author{
Nadine Bauer ${ }^{1, *}$, Hans-Peter Grossart ${ }^{2}$, Sabine Hilt ${ }^{1}$ \\ ${ }^{1}$ Leibniz-Institute of Freshwater Ecology and Inland Fisheries, Müggelseedamm 301, 12587 Berlin, Germany \\ ${ }^{2}$ Leibniz-Institute of Freshwater Ecology and Inland Fisheries, Department of Limnology of Stratified Lakes, \\ Alte Fischerhütte 2, 16775 Stechlin-Neuglobsow, Germany
}

\begin{abstract}
We investigated whether bacteria affect the sensitivity of Stephanodiscus minutulus (diatom) and Desmodesmus armatus (green alga) to tannic acid (TA). TA is a water soluble secondary plant metabolite which is released by submerged macrophytes and acts as an allelochemical because of its polyphenolic nature. Sensitivity of $S$. minutulus and D. armatus to TA changed in the presence of specific bacterial communities and bacterial isolates growing on TA. Without bacteria, growth of $S$. minutulus was inhibited by TA whereas the presence of bacteria pre-treated with high TA concentrations led to increased algal growth. Addition of sterile TA degradation products of bacterial isolates reduced inhibition of $D$. armatus. Differences in algal growth after TA addition were accompanied by changes in bacterial community composition (BCC) detected by DGGE and subsequent sequencing. This indicates that phytoplankton sensitivity to TA can be mediated by accompanying bacteria due to changes in BCC, which in turn are influenced by pre-treatment (different TA concentrations) and mode of addition of allelochemicals (pulsed or semi-continuous). Our study demonstrates that effects of allelochemicals on algal growth can be substantially changed by interference with microorganisms, which has not previously received attention.
\end{abstract}

KEY WORDS: Allelochemicals · Macrophyte-bacteria-phytoplankton interaction • Bacteria communities $\cdot$ Sensitivity test $\cdot$ Tannic acid

\section{INTRODUCTION}

Allelochemicals released by submerged macrophytes can inhibit the growth of phytoplankton (Gross 2003) and are thought to stabilize the clear-water regime in shallow lakes (Scheffer et al. 1993, Hilt \& Gross 2008). In situ evidence for this mechanism is hard to obtain (Hilt et al. 2006) and most of the studies on allelopathic effects on phytoplankton have thus been carried out at laboratory scale (Hilt \& Gross 2008). These studies show large differences in algal or cyanobacterial sensitivity to allelochemicals (Gross et al. 1996, Nakai et al. 1999, Körner \& Nicklisch 2002, Hilt 2006), but their causes and potential relevance in aquatic systems are not yet known.
A major unsolved question concerns the potential interference with microbial communities either associated with phytoplankton or in the ambient medium. Available studies on the effects of allelochemicals on phytoplankton have either used axenic algal cultures or xenic conditions with an undefined bacterial community composition (BCC). Both approaches impede an assessment of the potential effect of bacteria, which may metabolize allelochemicals (Müller et al. 2007), transform them biochemically (Scalbert 1991), build mechanical barriers such as extracellular polysaccharides (Decho 1990), or otherwise interact with the phytoplankton species via symbiosis, commensalism or antagonism (Cole 1982, Grossart 1999). Thus, bacteria have the potential to modify the sensitivity of phytoplankton to allelochemicals. 
A common group of allelochemicals produced and released by submerged macrophytes are polyphenols (Gross 2003). Due to inhibition of the activity of enzymes such as alkaline phosphatase, they affect phytoplankton growth (Gross et al. 1996) and inhibit photosystem II (Körner \& Nicklisch 2002). Polyphenols exhibit antimicrobial properties (Walenciak et al. 2002, Buzzini et al. 2008) and serve as substrate for polyphenol-degrading bacteria (Müller et al. 2007). Initial indications of a significant influence of bacteria on phytoplankton sensitivity to polyphenols stem from our previous study on the effect of tannic acid (TA) on the growth of axenic and xenic cultures of a green alga, Desmodesmus armatus (Bauer et al. 2008). Both positive and negative effects of bacteria on algal sensitivity to TA were found, which depended on initial algal biomass, bacteria:algae ratio, and effective concentration of the allelochemical (Bauer et al. 2008). In our previous study, however, we could not distinguish whether changes in phytoplankton-bacteria interactions were related to changes in BCC and/or bacterial modifications of added allelochemicals. Therefore, we aimed to further clarify bacterial effects on phytoplankton sensitivity to allelochemicals by investigating effects of changes in BCC after TA additions. Our main goals were to (1) elucidate effects of TA on BCC and bacterial growth, (2) study bacterial alteration of algicidal effects of TA, and (3) verify whether specific bacteria isolates alter algicidal effects of TA by decreasing TA concentration.

\section{MATERIALS AND METHODS}

Enumeration of bacteria. At the start and the end of pre-treatment and sensitivity test, $1 \mathrm{ml}$ of stained sample was filtered through black $0.2 \mu \mathrm{m}$ Nucleopore membranes to determine bacterial abundance. Bacteria were stained with the LIVE/DEAD Bacterial Viability Kit (Invitrogen) to check for viable bacteria and with 4',6-diamidino-2-phenylindole (DAPI, $0.2 \mathrm{mg}$ $100 \mathrm{ml}^{-1}$; Porter \& Feig 1980) for enumeration under an epifluorescence microscope (Axioskop, 130 VA Type $\mathrm{B}$, Zeiss) at $1000 \times$ magnification. At least 10 microscopic fields were counted (Grossart et al. 2003).

DGGE and subsequent sequencing. BCC was analysed by DGGE after DNA extraction and PCR amplification of 16S rRNA gene fragments according to Allgaier \& Grossart (2006). Cluster analyses of DGGE profiles were performed using the software GELCompar II, version 3.5 (Applied Maths), UPGMA and the Dice correlation index. DNA from single DGGE bands was re-amplified for sequencing using the primers GM5 without GC clamp and 907RM and the PCR protocol of Grossart et al. (2005). Re-amplified DNA was se- quenced using the BigDye Terminator v3.1 cycle sequencing kit (Applied Biosystems), the IRDye800labelled primer pair GM5 and 907RM, and an ABI Prism 3100-Avant genetic analyser (Applied Biosystems). Sequences were compared with those of reference organisms by BLAST search (www.ncbi.nlm. nih.gov/blast). The taxonomy browser of the NCBI server was used for determination of phylogenetic affiliation. All sequences were submitted to the NCBI gene bank (accession nos. GQ332384 to GQ332398).

Algal cell counts, biovolume, and growth rate. Abundance and size of algal cells were measured by a Cell counter (CASY ${ }^{\circledR}$, Modell TTC, measure version 1.5, Schärfe System). Minimal fluorescence $\left(F_{0}\right)$ was determined using a Xe-PAM (pulse amplitude modulation) fluorometer (Heinz Walz, 1998). For interpretation of $F_{0}$ see Jakob et al. (2005). Growth rates $(\mu)$ of algae were calculated from $F_{0}$ (Körner \& Nicklisch 2002), biovolume and algal cell number determined at the start $\left(t_{0}\right)$ and end $\left(t_{1}\right)$ of incubation:

$$
\mu=\frac{\ln \left(F_{0 t_{1}}\right)-\ln \left(F_{0 t_{0}}\right)}{\Delta t}
$$

where $\mu=$ growth rate $\left(\mathrm{d}^{-1}\right), F_{0 t_{0}}=$ minimal fluorescence at the beginning of incubation, $F_{0 t_{1}}=$ minimal fluorescence at the end of incubation, and $\Delta t=$ time of incubation (d).

This approximation is only appropriate for comparing values of the same algal species under equally maintained culture conditions. Thus, we always measured at the same time of the day under identical light conditions. We used low cell numbers (low chlorophyll $a$ [chl a] concentrations) to ensure exponential algal growth and to minimize self-shading effects. To avoid background interference with humic substances, we used the culture medium with $1 / 3$ lake water for adjustment of the zero offset.

Expt 1. Effects of allelochemicals on bacteria. Incubation of bacteria with TA: A natural bacterial community was sampled in autoclaved 11 Schott Duran bottles from a lake rich in dissolved organic carbon (DOC) (Krumme Laake, Berlin, $52^{\circ} 25.00^{\prime} \mathrm{N}$, $\left.13^{\circ} 41.15^{\prime} \mathrm{E}\right)$. The lake is characterized by a monospecific stand of Myriophyllum verticillatum L. (Haloragaceae), a submerged macrophyte that exudes algicidal hydrolysable polyphenols (Hilt et al. 2006, Bauer et al. 2009). Water samples were taken in autumn 2007 $(\mathrm{pH}=6.8)$ when degrading bacterial activity is assumed to be high due to a high amount of decaying plant material. The water was filtered through a sterile $30 \mu \mathrm{m}$ gauze to remove most of the zooplankton and incubated in autoclaved $500 \mathrm{ml}$ Erlenmeyer flasks mixed (1:1) with a nutrient-rich culture medium (MIIIKS, for nutrient composition see Körner \& Nicklisch 2002; $\mathrm{pH}=8.3$ ) to a final $\mathrm{pH}$ of $7.5 \pm 0.3$. TA (Fluka, fill- 
ing code: 403955/1 64400), a hydrolysable polyphenol, was added at high $\left(\mathrm{H}_{;} 0.5 \%\right)$ and low $(\mathrm{L} ; 0.05 \%)$ concentrations, whereas controls $\left(\mathrm{C}_{i} 0 \%\right)$ contained no TA. The end of the pre-treatment (Expt 1) coincided with the first day of the algal culture under TA influence (Expt 2; Fig. 1). To adapt bacteria to conditions of the subsequent sensitivity experiment (Expt 2), cultures were incubated for $7 \mathrm{~d}$ under constant rotation at $20^{\circ} \mathrm{C}$ in a $12 \mathrm{~h}$ light:12 h dark cycle with a solar irradiance (PAR) of $\sim 90 \mu \mathrm{mol}$ photons $\mathrm{m}^{-2} \mathrm{~s}^{-1}$ (Osram, 36W/ 72-965, 830 Biolux). To fully remove natural phytoplankton and to minimize protozoan grazing, the water was filtered through $3 \mu \mathrm{m}$ Nucleopore membranes (Whatman). Living bacteria and total bacteria were counted at the start and the end of all incubations with TA (Expt 1) and growth rates were calculated.

DGGE-analysis and sequencing of bacteria following TA incubation: A total of $150 \mathrm{ml}$ of each treatment were sequentially filtered onto 5.0 (for attached bacteria) and $0.2 \mu \mathrm{m}$ (for free-living bacteria) Nucleopore membranes (Whatman) and stored at $-20^{\circ} \mathrm{C}$ until further processing (see above DGGE) after pre-treatment with TA.
Phylogenetic analysis: Partial 16S rRNA gene sequences were phylogenetically analysed using the ARB software package (http://arb-home.de). The retrieved sequences were imported into an ARB database of 52000 reference sequences including the closest related sequences determined by BLAST (www. ncbi.nlm.nih.gov/blast/). To increase the robustness of the phylogenetic calculations and to exclude potential alignment errors, a $50 \%$ base frequency filter for Eubacteria was calculated.

Expt 2. Bacteria-mediated effects on algal sensitivity to allelochemicals. Sensitivity test: Effects of different, pre-treated bacterial communities on algal sensitivity to allelochemicals were tested using the axenic diatom Stephanodiscus minutulus (Kütz) Cleve \& Möller (Bacillariophyta, culture collection of the Humboldt University of Berlin, strain HUB 082, isolated from Lake Müggelsee and kindly provided by A. Nicklisch). S. minutulus is a representative of eutrophic waters (and also occurs in the lake from which bacteria were sampled) and was cultured axenically in a sterile-filtered culture solution at $20^{\circ} \mathrm{C}$ under the same light conditions as mentioned above. Inocula of $20 \mathrm{ml}$ bacteria $(\mathrm{C}, \mathrm{L}$, and $\mathrm{H}$ pre-

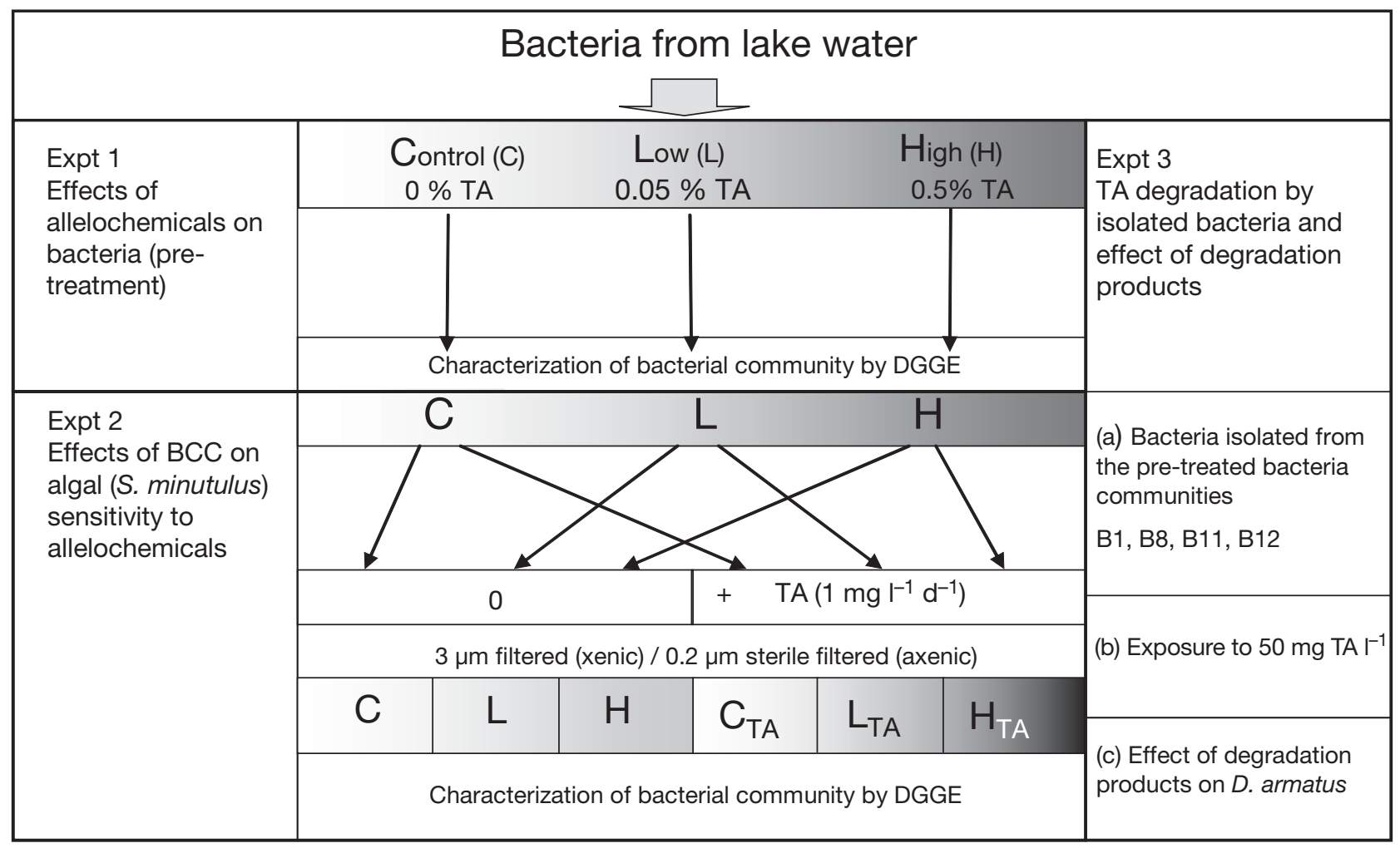

Fig. 1. Stephanodiscus minutulus and Desmodesmus armatus. Expt 1: pre-adaptation of a bacterial community from lake water exposed to different concentrations of tannic acid (TA) for $7 \mathrm{~d}$ (C: control, $0 \%$ TA; L: low, $0.05 \%$ TA; H: high, 0.5\% TA). Expt 2: incubation of $S$. minutulus with pre-treated bacteria (xenic), and without bacteria (axenic) but with sterile-filtered culture medium of the respective treatments. BCC: bacterial community composition. C, L, H: bacterial community TA pre-treatments without further TA addition. $\mathrm{C}_{\mathrm{TA}}, \mathrm{L}_{\mathrm{TA}}, \mathrm{H}_{\mathrm{TA}}$ : respective bacterial communities treated daily with $1 \mathrm{mg}^{\mathrm{TA}} \mathrm{l}^{-1}$. Expt 3: (a,b) TA degradation by isolated bacteria, and (c) effects of degradation products on growth and photosynthetic activity of $D$. armatus. Shading shows increasing concentrations of TA 
treatments, adjusted to $10^{6}$ cells ml $^{-1}$; Fig. 1) were added to $40 \mathrm{ml}$ axenic $S$. minutulus (Expt 2; Fig. 1). The diatom was kept in batch culture with a low start concentration to ensure exponential growth over most of the incubation time. The algae start concentration was adjusted to chl a $\left(F_{0}\right)=5 \mu \mathrm{g} \mathrm{l}^{-1}$ using a Phyto-PAM fluorometer (Walz). This corresponds to a chl a content of about $25 \mu \mathrm{g} \mathrm{l}^{-1}$ according to Körner \& Nicklisch (2002). The axenic and xenic algae were cultured in $100 \mathrm{ml}$ Erlenmeyer flasks under constant gentle rotation and consisted of $1 / 3$ bacteria inocula in lake water, $1 / 3$ algae suspension and 1/3 fresh culture medium (MIIIKS, $\mathrm{pH}=7.5 \pm 0.3$ ). The TA stock solution (1 $\mathrm{mg} \mathrm{ml}^{-1}$ ) was freshly prepared every day with sterile-filtered distilled water, ultrasonicated for complete dissolution, sterile-filtered through a $0.2 \mu \mathrm{m}$ Nucleopore membrane, and stored in the dark at $4^{\circ} \mathrm{C}$ until further processing. Semi-continuous addition of TA (0.001 $\mathrm{mg} \mathrm{TA} \mathrm{ml}^{-1} \mathrm{~d}^{-1}$ ) to $S$. minutulus (TA treatments: $\mathrm{C}_{\mathrm{TA}}, \mathrm{L}_{\mathrm{TA}}, \mathrm{H}_{\mathrm{TA}}$, Expt 2; Fig. 1) and sterile-filtered distilled water as controls (C, L, H, Expt 2; Fig. 1) lasted for $7 \mathrm{~d}$ in the presence and absence (axenic filtrates) of different pre-treated bacterial communities. For each treatment, 3 replicates were conducted. Growth rates of $S$. minutulus were calculated as described above. To detect differences due to pre-treatment with different bacterial communities, we compared the growth rates of the diatom by 1-way analysis of variance (ANOVA) and subsequent Tukey's post-hoc test. The effect of additional TA exposure was tested using the Student's $t$-test. All statistical tests were performed with the standard version of SPSS for Windows 9.0.1 (SPSS).

Characterization of $B C C$ in coexistence with Stephanodiscus minutulus: We compared the different BCC pre-treated with TA before and after $7 \mathrm{~d}$ of exposure to $S$. minutulus by their DGGE profiles. We used cluster analysis with UPMA and Dice correlation index separately for both free-living and attached bacteria.

Expt 3. TA degradation by isolated bacteria and effects of degradation products on algal growth. Isolation of polyphenol-degrading bacteria: Bacteria were isolated from Lake Krumme Laake in October 2007. The isolated bacteria strains were tested for growth on TA as the sole carbon source in medium B (Müller et al. 2007). Isolated bacteria were enriched on DEV-nutrient agar plates (Fluka, filling code: 1124826 $54406181)$ to enable faster growth of colonies. The plates were cultivated at $16^{\circ} \mathrm{C}$ in the dark. Successively growing cultures were transferred to sterilefiltered (0.2 $\mu \mathrm{m}$ Sterivex-Millipore) lake water sampled in June, when allelopathic activity of submerged macrophytes is supposed to be high (Hilt et al. 2006). Cultures were cultivated at $20^{\circ} \mathrm{C}$ and checked weekly for single species culture on DEV-nutrient agar plates. Growth rates of bacteria were determined by enumeration at the start and at the end of incubation.
Identification of TA-utilizing bacteria isolates on the basis of 16S rDNA: A total of 12 isolated bacteria strains were visually checked using an epifluorescence microscope after DAPI staining for formation of single species cell colonies on DEV-nutrient agar plates. For the degradation experiment, 4 different isolates were selected after DGGE and subsequent sequencing of their DGGE bands (see paragraph above).

Bacterial degradation of TA: The 4 selected bacterial strains (B1, B8, B11, B12) were pre-cultured in lake water for $4 \mathrm{wk}$ at $20^{\circ} \mathrm{C}$ at the same light conditions to adapt the bacteria to experimental conditions as used in the sensitivity test (Expt 1) and adjusted to a cell density of $10^{6}$ cells ml $\mathrm{m}^{-1}$ at the start of Expt 3 . They were cultured with TA (50 $\mathrm{mg} \mathrm{l}^{-1}$ start concentration) and without TA in sterile mixture of lake water (1/3) and MIIIKS (2/3), $(\mathrm{pH}=7.5 \pm 0.3)$ for $7 \mathrm{~d}$. Bacterial cultures were then passed through a pre-rinsed and pre-combusted $0.45 \mu \mathrm{m}$ cellulose acetate membrane (Whatman), and the remaining TA in solution was detected after reaction with Folin-Ciocalteau (Box 1983) reagent by a UV-VIS scanning spectrophotometer (UV-2101 PC, Shimadzu) as concentration of total phenolic compounds (TPC). To test for significant effects of bacteria as compared to the respective axenic controls and for species-specific effects of the tested bacterial strains, we performed a 1-way ANOVA with subsequent Tukey's post-hoc test comparing TPC concentrations at the end of Expt 3.

Test of phytoplankton sensitivity to bacterial degradation products: Effects of bacterial degradation products of TA on algae growth rates were tested on axenic cultures of the chlorophyte Desmodesmus armatus (Chodat) E. Hegewald (SAG, 276-4e). Previously, we have shown variable effects of TA on $D$. armatus in cultures with pre-adapted bacteria (Bauer et al. 2008). Due to its broader tolerance at high TA concentrations (used for bacterial degradation), we have selected this species instead of the diatom. The culture medium of the bacteria with and without TA was sterile filtered (0.2 $\mathrm{mm}$ Sterivex, Millipore) twice and added to axenic $D$. armatus cultured in reagent tubes at $20^{\circ} \mathrm{C}$ under $12 \mathrm{~h}$ light:12 h dark conditions. All tubes were 3/4 filled and permanently rotated to prevent lack of oxygen. $F_{0}$ was measured at the start of incubation with TA degradation products and after $7 \mathrm{~d}$ of exposure to the degradation products to calculate growth rates as mentioned above. To test for species-specific effects of isolates, we performed a 1-way ANOVA with subsequent Tukey's post-hoc test comparing growth rates of the green alga in the presence of the respective degradation products of the tested bacterial isolates. Differences in growth rate between treatment and control were tested with Student's $t$-test. 


\section{RESULTS}

\section{Effects of allelochemicals on bacteria during pre-treatment (Expt 1)}

Bacterial growth rates were not influenced during pre-treatment with TA (ANOVA, p > 0.05 for all treatments; Table 1). Abundance of living bacteria at the end of the pre-treatment, however, was significantly higher in the high $(\mathrm{H}) \mathrm{TA}$ treatment $\left(1.5 \pm 0.1 \times 10^{6}\right)$ as compared to the low $(\mathrm{L}) \mathrm{TA}$ treatment $\left(0.9 \pm 0.02 \times 10^{6}\right)$ (ANOVA, $\mathrm{p}=0.001, F=27.5$ ). We clustered the DGGE banding patterns of Expts 1 and 2 to follow changes in BCC between both experiments (but separately for attached and free-living bacteria). Cluster analysis of free-living bacteria revealed subclusters for both experiments and sub-clusters between $\mathrm{L}$ and $\mathrm{H}$ TA treatment (Fig. 2A; $\mathrm{H}, \mathrm{L}$ ). These clusters were clearly different from the control (C) (Fig. 2A,C). BCC of attached bacteria formed a sub-cluster with $\mathrm{C}$ and $\mathrm{L}$ of Expt 1 (Fig. 2B), which was clearly different from that of the high TA addition. The DGGE band numbers of attached bacterial communities increased successively from $\mathrm{C}$, L and $\mathrm{H}$ TA treatments.

DGGE bands which showed a new or representative emergence in the different pre-treatments were selected. These bands were identified on the basis of alignment of their partial 16S rDNA sequences with closely related sequences of the NCBI gene bank (March 2009). The results are presented in a phylogenetic tree (Fig. 3) and in Table S1 and Fig. S1 in

A

B $\begin{array}{lllll}20 & 40 & 60 & 80 & 100\end{array}$

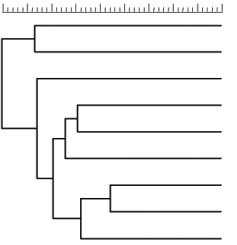

the supplement at www.int-res.com/articles/suppl/ a059p295_app.pdf. Attached bacteria of the untreated samples (C) of Expt 1 are characterized by acidophilic Betaproteobacteria such as Acidovorax sp. and Rhodoferrax ferrireducens (Comamonadaceae). In the freeliving bacteria fraction, however, we found potential pathogens such as Legionella sp. (Gammaproteobacteria). For further analysis of $\mathrm{BCC}$, we focused on attached bacteria because bacteria-mediated effects on phytoplankton sensitivity to allelochemicals are assumed to be stronger in this fraction. In Expt 1, additions of low TA (L) served as an additional carbon source and shifted the BCC towards a more diverse community including Betaproteobacteria of the Burkholderiales, e.g. Limnobacter sp., and AlphaproteoDGGE1 DGGE1

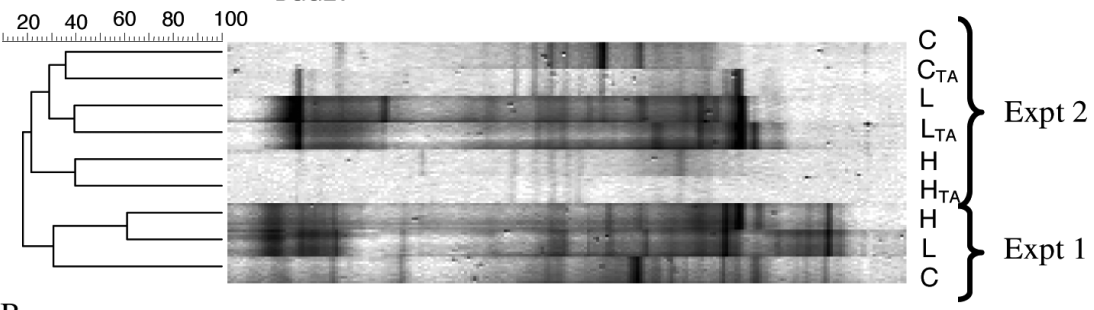
DGGE1 DGGE1
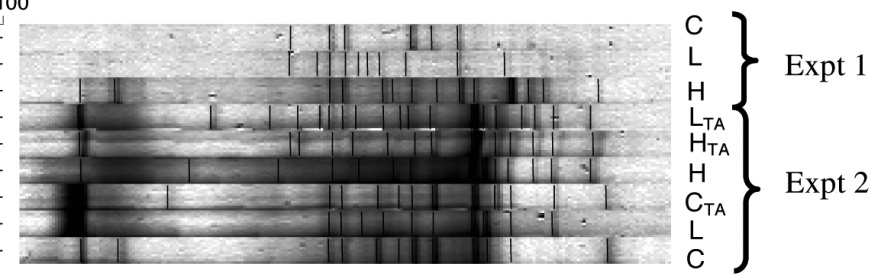

Fig. 2. Stephanodiscus minutulus. Dendrogram of cluster analysis of DGGE banding patterns: (A) free-living and (B) attached bacteria. C, L, H: pre-treated bacterial community in Expt 1 to no (control, $0 \%$ ), low $(0.05 \%)$ and high $(0.5 \%)$ tannic acid (TA) concentrations. Respective Expt 2 bacterial communities cultivated with $S$. minutulus with daily TA addition $\left(1 \mathrm{mg} \mathrm{l}^{-1}\right)\left(\mathrm{C}_{\mathrm{TA}}, \mathrm{L}_{\mathrm{TA}}, \mathrm{H}_{\mathrm{TA}}\right)$ and without further TA addition ( $\mathrm{C}, \mathrm{L}, \mathrm{H})$ (see Fig. 1)

Table 1. Growth rates (mean $\pm \mathrm{SE}$ ) of living bacteria and total bacteria during pre-treatment (Expt 1), and co-culture with Stephanodiscus minutulus (Expt 2) for the pre- and daily tannic acid (TA) treatments. C: control, $0 \% \mathrm{TA} ; \mathrm{L}:$ low, $0.05 \% \mathrm{TA} ; \mathrm{H}$ : high, $0.5 \%$ TA. Significant differences in growth rates between pre-treatments indicated by superscript letters and bold, and refer to $\mathrm{p}<0.001$, tested with ANOVA and a subsequent Tukey-B post-hoc test

\begin{tabular}{|c|c|c|c|c|}
\hline \multirow{2}{*}{$\begin{array}{l}\text { TA } \\
\text { conc. }\end{array}$} & \multicolumn{4}{|c|}{ Growth rate $\left(\mathrm{d}^{-1}\right)$} \\
\hline & $\begin{array}{l}\text { Living bacteria } \\
\text { (TA pre-treatment) }\end{array}$ & $\begin{array}{c}\text { Total bacteria } \\
\text { (TA pre-treatment) }\end{array}$ & $\begin{array}{l}\text { Living bacteria } \\
\text { (TA daily treatment) }\end{array}$ & $\begin{array}{c}\text { Total bacteria } \\
\text { (TA daily treatment) }\end{array}$ \\
\hline \multicolumn{5}{|l|}{ Expt 1} \\
\hline $\mathrm{C}$ & $0.63 \pm 0.003$ & $0.64 \pm 0.012$ & & \\
\hline $\mathrm{L}$ & $0.65 \pm 0.013$ & $0.61 \pm 0.027$ & & \\
\hline $\mathrm{H}$ & $0.59 \pm 0.011$ & $0.56 \pm 0.014$ & & \\
\hline \multicolumn{5}{|l|}{ Expt 2} \\
\hline $\mathrm{C}$ & $0.19 \pm 0.027^{a}$ & $0.26 \pm 0.02$ & $0.36 \pm 0.043$ & $0.30 \pm 0.04$ \\
\hline $\mathrm{L}$ & $0.25 \pm 0.014^{\mathrm{a}}$ & $0.28 \pm 0.01$ & $0.48 \pm 0.037$ & $0.38 \pm 0.03$ \\
\hline $\mathrm{H}$ & $0.34 \pm 0.012^{b}$ & $0.26 \pm 0.005$ & $0.36 \pm 0.05$ & $0.27 \pm 0.05$ \\
\hline
\end{tabular}




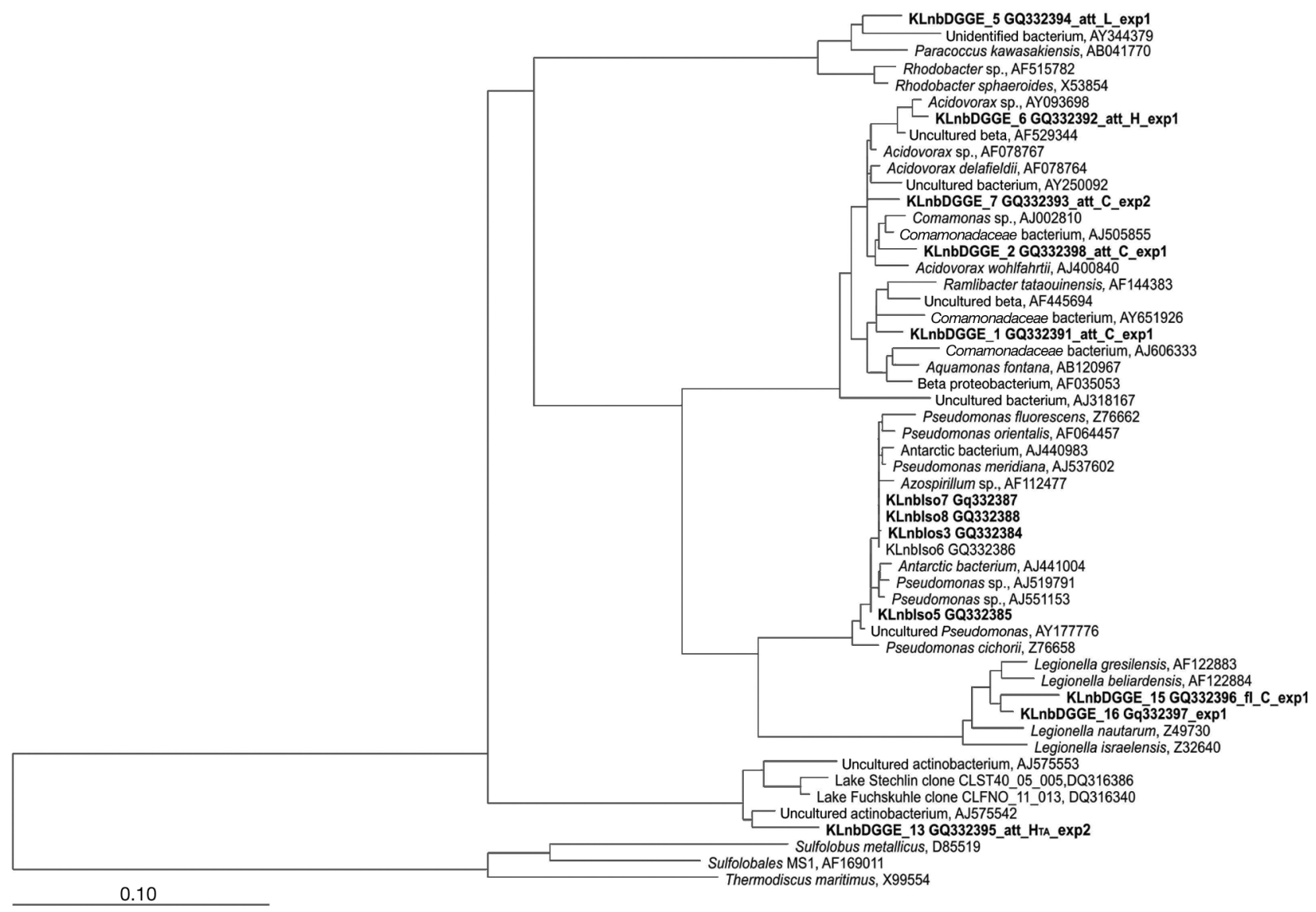

Fig. 3. Phylogenetic (neighbour joining) tree based on 16S rDNA sequences showing the relationship of representatives of DGGE bands of attached (att) and free-living bacteria (fl) with different tannic acid (TA) addition during pre-treatment (Expt 1, C: no, L: low and H: high TA concentrations) and in sensitivity test (Expt 2) without $(\mathrm{C}, \mathrm{L}, \mathrm{H})$ and with $\left(\mathrm{C}_{\mathrm{TA}}, \mathrm{L}_{\mathrm{TA}}, \mathrm{H}_{\mathrm{TA}}\right)$ further TA addition. Phylogenetic affiliation of sequenced DGGE bands (indicated by DGGE and GenBank accession number labels) and isolates (indicated by 'Iso') of Lake Krumme Laake enriched with TA as the sole carbon source is given in Table S1 in the supplement (www.int-res.com/articles/suppl/a059p295_app.pdf)

bacteria, e.g. Rickettsia canadensis and Rhodobacter sphaeroides. Additions of high TA $(\mathrm{H})$ resulted in the occurrence of Actinobacteria (Streptomyces) and Betaproteobacteria of the Comamonadaceae (Rhodoferrax ferrireducens).

\section{Effects of TA treatment and BCC during algae exposure (Expt 2)}

Bacterial abundance increased during cultivation with Stephanodiscus minutulus (Expt 2), but the average growth rate of bacteria $\left(0.31 \pm 0.02 \mathrm{~d}^{-1}\right)$ was reduced to almost half of the overall growth rate of bacteria in Expt $1\left(0.61 \pm 0.01 \mathrm{~d}^{-1}\right)$. At the end of Expt 2 , bacteria abundance ranged from $0.66 \pm 0.06 \times 10^{7}$ cells $\mathrm{ml}^{-1}$ for the $\mathrm{L}$ pre-treatment to $0.8 \pm 0.09 \times 10^{7}$ cells $\mathrm{ml}^{-1}$ for the $\mathrm{H}$ pre-treatment without further TA addition. With further TA addition, however, they increased from $1.1 \pm 0.36$ cells ml ${ }^{-1}$ in $\mathrm{H}_{\mathrm{TA}}$ to $1.36 \pm 0.25$ $\times 10^{7}$ cells $\mathrm{ml}^{-1}$ in $\mathrm{C}_{\mathrm{TA}}$. Growth rates of living and total bacteria did not differ between treatments with further TA addition (Table 1; ANOVA, p > 0.05). However, living bacteria without further TA addition and pretreated with the $\mathrm{H}$ concentration revealed a significantly higher growth rate $\left(0.34 \mathrm{~d}^{-1}\right)$ as compared to $\mathrm{C}$ and $\mathrm{L}$ (0.19 and $0.25 \mathrm{~d}^{-1}$, respectively) (Table 1; ANOVA, $p=0.004, F=16.59$ ). This pattern is consistent with the cluster analysis of the respective DGGE banding patterns of attached bacteria (Fig. 2B). BCC of attached bacteria with further TA additions clustered together $\left(\mathrm{L}_{\mathrm{TA}}, \mathrm{H}_{\mathrm{TA}}, \mathrm{H}_{i}\right.$ Fig. $\left.2 \mathrm{~B}\right)$ and were clearly different from $\mathrm{C}_{\mathrm{TA}}, \mathrm{L}$, and C. Free-living bacteria exposed to TA in the presence of $S$. minutulus were grouped into 3 distinct sub-clusters depending on the pre-treatment (Fig. 2A): (1) treatments with no TA (C, $\mathrm{C}_{\mathrm{TA}}$ ), (2) low TA exposure $\left(\mathrm{L}, \mathrm{L}_{\mathrm{TA}}\right)$, and (3) high TA exposure $\left(\mathrm{H}, \mathrm{H}_{\mathrm{TA}}\right)$ independent of further TA additions in Expt 2. 
Amongst bacteria in the control of Expt 1, which was later treated with TA together with Stephanodiscus minutulus in Expt $2\left(\mathrm{C}_{\mathrm{TA}}\right)$, Betaproteobacteria related to Delftia acidovorans SPH-1 were found. When pretreated with low TA concentrations ( $\mathrm{L}$ and $\mathrm{L}_{\mathrm{TA}}$ ), however, Alphaproteobacteria (e.g. Erythrobacter litoralis) occurred. In contrast, when pre-treated with high TA concentrations $\left(\mathrm{H}\right.$ and $\mathrm{H}_{\mathrm{TA}}$ ), bacteria were affiliated with Actinobacteria closely related to an uncultured clone (AJ575542) of humic Lake Grosse Fuchskuhle (Burkert et al. 2003, Allgaier \& Grossart 2006) (Fig. 3). Rhodoferax ferrireducens (Burkholderiales, Comamonadaceae) occurred in the bacterial community pretreated with high TA concentrations $(\mathrm{H})$ and also in the untreated bacterial community $(\mathrm{C})$.

\section{Bacteria mediated effects on algal sensitivity to allelochemicals}

Effects of specific bacterial communities on the sensitivity of Stephanodiscus minutulus to TA were detected by comparing growth rates of axenic and xenic $S$. minutulus after TA addition. Growth rates based on biovolume and cell counts gave the same tendency as growth rates based on $F_{0}$ but reacted with a time delay and, therefore, are not presented. Growth rates (based on $F_{0}$ ) of axenically cultured $S$. minutulus incubated with filtrate of the high TA pre-treatment were strongly inhibited resulting in negative values for $\mathrm{H}$ and $\mathrm{H}_{\mathrm{TA}}$. This effect was independent of further TA addition (Fig. 4C,D) when compared to the positive growth of treatments with filtrates of $\mathrm{C}, \mathrm{C}_{\mathrm{TA}}, \mathrm{L}$, and $\mathrm{L}_{\mathrm{TA}}$ (ANOVA, $\mathrm{p}<0.001, F=22.6$; Fig. 4C,D). In xenic cultures, the presence of high TA pretreated bacteria without further TA addition $(\mathrm{H})$ resulted in increased algal growth compared to growth with bacteria not pre-treated with TA $(\mathrm{C})$ or with low TA (L) (ANOVA, p = 0.001, $F=$ 26.3; Fig. 4A). Further addition of TA to algal cultures with bacteria pre-treated with high $\left(\mathrm{H}_{\mathrm{TA}}\right)$ and low $\left(\mathrm{L}_{\mathrm{TA}}\right) \mathrm{TA}$, however, led to reduced growth of $S$. minutulus (ANOVA, $\mathrm{p}=0.01, \quad F=11$; Fig. 4B).

\section{TA degradation by bacteria isolates}

All bacteria isolated from bacterial communities pre-adapted to different TA concentrations belonged to pseudo- monads (Gammaproteobacteria). The sequenced Isolates B5, B6, B7, B8 and B12 were specified as Pseudomonas sp., whereas Isolate B11 is identical to P. putida (Fig. 3, Table S1). Isolates B3 (D. Li \& M. Yang unpubl. data) and B6 are related to some antibiotic resistant strains. Isolates B7 and B8 are identical and closely related to pyrene degrading bacteria. Strains B8, B1 (one unidentified bacterium) as well as Isolate B11 (related to a quinolene degrading bacterium) and Isolate B12 (related to a bacterium involved in sulphur oxidation) were used for TA degradation experiments (Expt 3).

Without addition of TA, concentrations of TPC of bacteria isolates (B1, B8, B11, and B12) did not significantly differ from the control (ANOVA, $\mathrm{p}=0.291$, $F=1.44$; Fig. 5). Thus, differences in background TPC concentrations should not have influenced the following TA degradation experiment. After addition of TA, bacteria isolates reduced the initial TA concentration $\left(50 \mathrm{mg} \mathrm{l}^{-1}\right.$ ) by 74 to $82 \%$. Between treatments, we noticed species-specific differences with Isolates B11 and B12 being the most effective TA degraders. In contrast, Isolates B1 and B8 were less effective but still reduced TA concentration significantly as compared to the control (ANOVA, p < 0.001, $F=42.6$; Fig. 5). Unfortunately, in the respective axenic cultures we detected some bacteria colonies at the end of the experiment that may have reduced the real effect on algal growth.

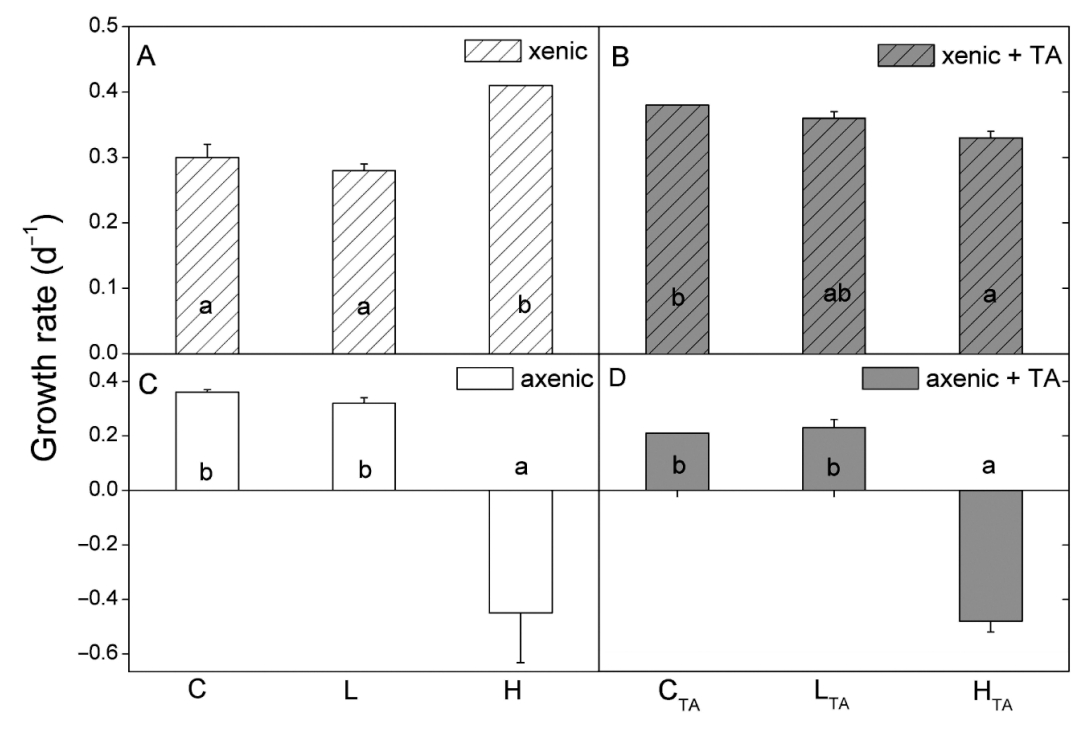

Fig. 4. Stephanodiscus minutulus. Growth rates (mean $\pm \mathrm{SE}$ ) of $S$. minutulus $(\mathrm{A}, \mathrm{B})$ with bacteria (hatched bars) pre-treated with no (control, C), low (L), and high $(\mathrm{H})$ concentrations of tannic acid (TA) and (C,D) without bacteria but with sterile-filtered culture medium of the bacteria. TA was added daily to $\mathrm{C}_{\mathrm{TA}}, \mathrm{L}_{\mathrm{TA}}$, and $\mathrm{H}_{\mathrm{TA}}$ treatments (grey bars). Different lower case letters $(\mathrm{a}, \mathrm{b})$ indicate significant differences $(\mathrm{p}<0.05)$ between growth rates separately for each treatment (A to D) as calculated by 1-way ANOVA and subsequent Tukey-B post-hoc tests 


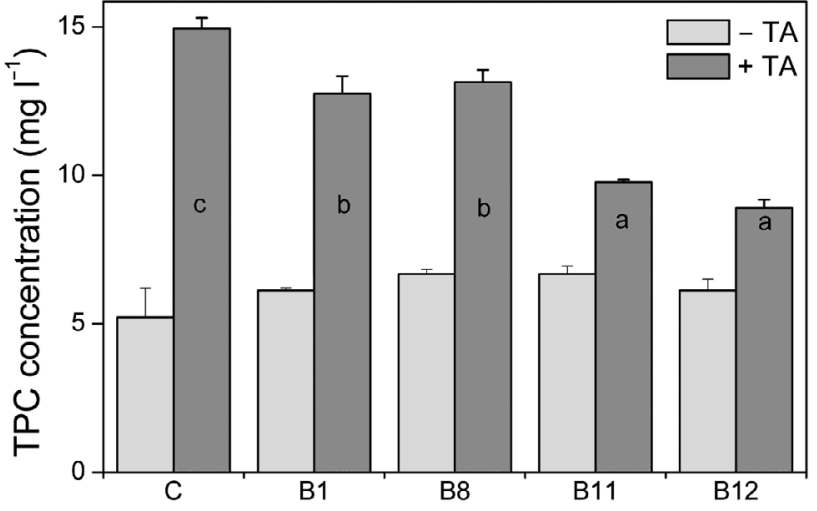

Fig. 5. Total phenolic compounds (TPC) concentrations (mean $\pm \mathrm{SE}$ ) of sterile-filtered culture medium without degradation (control, C) and after degradation by bacterial Isolates B1, B8, $\mathrm{B} 11$, and B12 exposed to $50 \mathrm{mg} \mathrm{l}^{-1}$ tannic acid (dark grey bars, $+\mathrm{TA}$ ) or no TA (light grey bars, -TA). Different lower case letters $(\mathrm{a}-\mathrm{c})$ indicate significant differences between TPC concentrations after TA degradation by bacterial isolates (B1, B8, B11, B12) and the control (C) $(\mathrm{p}<0.05)$ as calculated by 1 -way ANOVA and subsequent Tukey-B post-hoc tests. No significant differences occurred in treatments without TA exposure (light grey bars)

\section{Effects of TA degradation products on algal growth}

Growth rates of Desmodesmus armatus exposed to sterile-filtered culture solutions including metabolic products/enzymes of the different bacteria isolates without TA did not differ significantly from the axenic control (ANOVA, $p=0.277, F=1.491$; Fig. 6). This notion indicates that the bacteria culture medium without TA did not per se affect growth of the algae under these conditions. The effect of bacterial degradation products of TA was significantly weaker and revealed species-specific differences among isolates (ANOVA $\mathrm{p}<0.001, F=36$; Fig. 6). TA-degradation products always yielded lower growth rates of $D$. armatus compared to sterile-filtered culture medium of the respective bacterial isolates but still facilitated growth, whereas TA not exposed to bacterial degradation (C:

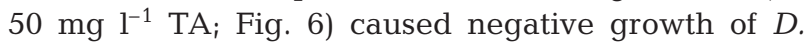
armatus. The degradation products of Isolate B8 and B12 reduced algal growth significantly compared to their respective control (with sterile-filtered bacterial culture medium) ( $\mathrm{p}<0.05, t$-tests; Fig. 6). In contrast, TA degradation products of Isolates B1 and B11 did not lead to a significant reduction in algal growth compared to the respective sterile-filtered culture medium of the bacteria. TA degradation products of Isolate B8 stopped growth of $D$. armatus. In the presence of degradation products of Isolate B11 and B12, which reduced TA concentrations most effectively, growth rate of $D$. armatus accounted for only 33 to $35 \%$ of that of the untreated control ( $C_{i}$ Fig. 6).

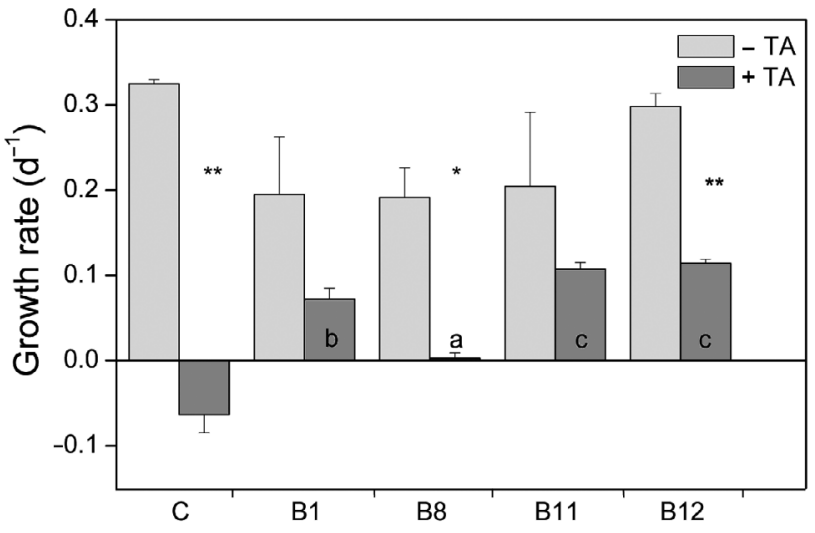

Fig. 6. Desmodesmus armatus. Growth rates (mean \pm SE) of the axenic green alga $D$. armatus without (-TA, light grey bars) and with (+TA, dark grey bars) exposure to tannic acid (TA) degradation products of different bacterial isolates (B1, B8, B11, B12) and bacteria-free culture medium (control, C). Different lower case letters $(\mathrm{a}-\mathrm{c})$ indicate significant differences $(p<0.05)$ between growth rates of $D$. armatus in the presence of different bacterial TA degradation products as calculated by 1-way ANOVA and subsequent Tukey-B posthoc tests (dark grey bars). No significant differences occurred between growth rates of algae without TA and its degradation products (light grey bars). ${ }^{*} \mathrm{p}<0.05,{ }^{* *} \mathrm{p}<0.01$ between $-\mathrm{TA} /+\mathrm{TA}$ treatments tested with Student's $t$-test

\section{DISCUSSION}

\section{Effects of allelochemicals on bacteria}

BCC always changed in the presence of TA and its degradation products and, moreover, bacterial activities mediated effects of TA on phytoplankton in various ways. Antibacterial properties of phenolic compounds are an important factor determining BCC in the surrounding water (Freeman et al. 1990, Buzzini et al. 2008). Inhibitory effects of phenolic compounds are mainly ascribed to interactions with enzymes (Freeman et al. 2001) and more generally to interference with proteins, amino acids, phospholipids and sugars (He et al. 2006). However, specific bacterial communities, e.g. in alpine soils, are not affected by polyphenols (Baptist et al. 2008) or even benefit from polyphenols by using them as a substrate (Chowdhury et al. 2004). TA pre-treatment of bacteria in our experiments resulted in higher DGGE band numbers, indicating a higher diversity of bacteria which presumably resist TA and/or benefit from the added TA as a carbon source. For the high TA pre-treatment, we used TA concentrations far above natural concentrations and bacteria from dense stands of polyphenol-exuding macrophytes to select for resistant and substrate-specific bacterial communities. These bacteria possess a variety of mechanisms to overcome inhibitory effects of tannins such as modification and degradation (Scalbert 
1991, Chowdhury et al. 2004), dissociation of tanninsubstrate complexes, tannin inactivation through high affinity binders, membrane modification and repair, or metal ion sequestration (Smith et al. 2005).

TA addition was selected for bacterial phylotypes that often occur in humic matter and phenol-rich environments. For example, bacteria closely related to Acidovorax sp. are widely distributed in humic lakes (Burkert et al. 2003, Newton et al. 2006, Grossart et al. 2008). Other representatives of Betaproteobacteria belonging to the Burkholderiales of the Comamonadaceae group (Limnobacter sp.) are common in lakes, especially with high humic matter content (Hutalle 2010). Furthermore, Alphaproteobacteria closely related to Rhodobacter sphaeroides are known for their ability to degrade oil mill waste or as test organisms for studying the uncoupling activity of phenols in energy transducing membranes (Escher et al. 1996, Funatogawa et al. 2004).

\section{Bacteria-mediated effects on algal sensitivity to allelochemicals}

Specific interactions between bacteria and phytoplankton such as competition for nutrients (Grossart 1999), removal of cyanotoxins in biofilms (Babica et al. 2005), and mineralization processes within algal aggregates (Grossart et al. 2003, 2005) indicate that bacteria have the potential to interfere with allelochemical effects on phytoplankton. We found no significantly reduced bacterial growth of bacteria at high TA concentrations that would indicate prevailing inhibitory effects of TA in the pre-treatment, but enhanced growth of bacteria adapted to high TA in co-culture with Stephanodiscus minutulus. Changes of DGGE banding pattern during incubation with TA and algae reflect that emerging bacteria can resist and/or degrade TA or even may benefit indirectly from TA influence, e.g. from algal exudates. This result is in line with the finding that bacterial dynamics in lakes are mainly driven by system-specific interactions with the phytoplankton (Kent et al. 2007).

Cluster analysis of DGGE banding patterns of attached bacteria revealed 3 clusters: no, low, and high TA according to pre-treatment. Our previous work shows that bacterial communities adapted to algae cultures through prolonged co-incubation have a stronger effect on algal sensitivity to TA than freshly introduced indifferent bacterial communities (Bauer et al. 2008). A possible explanation for this notion could be the formation of close interactions between algae and bacteria. In addition to TA, phytoplankton may also affect BCC since a higher bacterial diversity occurred in the presence of Stephanodiscus minutulus (with and without
TA). However, average bacterial growth rate was reduced in the presence of algae compared to overall bacterial growth in the pre-treatment. This observation suggests both direct and indirect effects of TA on bacteria-mediated effects on algal sensitivity. TA effects on the diatom may result in changes in the source and quality of dissolved organic matter (DOM) production or release, e.g. by increasing mucus polysaccharides or cell lyses. Such changes in DOM quality may alter their bioavailability and have consequences for BCC. The reduction in bacterial growth in the presence of the diatom could involve changes in DOM quality. Other factors such as virus infections, grazing, and nutrient limitation as well as antibiotic activity could also explain such decoupling effects (Abreu et al. 2003) but were not investigated in our experiment. TA addition favours TA-degrading bacteria, which lead to an accumulation of degradation products, nutrients, vitamins, secondary metabolites or signal molecules. Subsequent bacterial use of TA degradation products (derived from primary phenol degraders) and released nutrients (due to TA-induced mortality of organisms) in turn can enhance growth efficiencies of other members of the microbial community (DeRito et al. 2005). Hence, emergence of specific bacteria following TA addition can have multiple reasons.

In general, we sequenced DGGE bands of species induced by TA that are representative of phenol degrading bacteria. In treatments with TA of the natural bacterial community co-cultured with Stephanodiscus minutulus $\left(\mathrm{C}_{\mathrm{TA}}\right)$, we found a relative of Delftia acidovorans, a Betaproteobacteria belonging to the Burkholderiales (Comomonadacea) that is capable of growing on phenolic compounds (congeners of linear alkylbenzensulfonate as sulphophenylcarboxylates; Schleheck et al. 2004). Another specific bacterium, Rhodoferrax ferrireducens, was found under TA exposure but also in the untreated bacterial community sampled in the natural macrophyte stand. Thus, all sequenced bacteria are members of an already specialized, natural bacterial community or of a bacterial community adapted to TA additions. In our treatment, which is closest to natural conditions (bacteria cultured with the diatom, pre-treated with low TA concentration and repeatedly exposed to TA), we found Erythrobacter, a specific Alphaproteobacteria whose marine relatives possess epoxide hydrolase (Woo et al. 2007). This enzyme is involved in detoxification of phytochemicals and allelochemicals by metabolizing plant epoxides and is widely distributed in herbivorous arthropods (Mullin 1988).

For the first time, our results show that differences in phytoplankton Stephanodiscus minutulus sensitivity to TA can be assigned to the accompanying bacterial community. We previously showed that the presence 
of bacteria decreased TA-induced inhibition of algal Desmodesmus armatus growth, whereas higher algal biomass increased inhibition (Bauer et al. 2008). In that study, however, we could not address TA modifications by specific bacterial processes. In the present study, we are able to distinguish between (1) growth stimulation of algae exposed to bacteria fed by a single TA addition, (2) bacterial reduction of algal growth inhibition under repeated TA addition, and (3) concentration-dependent inhibition of axenic algae cultures by TA. Several bacterial interferences may modify inhibition of phytoplankton growth by TA, e.g. formation of physical barriers in biofilms by polymers or exoenzymes that complex with TA or possess degrading activity (Smith et al. 2005). Reversible processes that could explain changes in inhibitory properties with the mode of TA addition, e.g. inactivation of reactive sites of high affinity binders such as tannins, are known for DOM (Ervin \& Wetzel 2003). TA-resistant bacteria may modify allelochemical effects on phytoplankton by interfering with algicidal properties of TA and consequently prevent inhibitory effects. Repeated addition of TA, however, may cause irreparable harm to bacteria, e.g. membrane damage (e.g. Funatogawa et al. 2004). On the other hand, the reduced diversity of bacteria due to permanent TA addition may have caused limited TA degradation by the remaining bacterial community as indicated by studies of Bajaj et al. (2008) and Loh \& Wang (1998). In addition, incomplete or limited degradation of TA due to reduced bacterial diversity potentially led to persistent toxic reactions. Similar effects can be expected of allelochemicals continually released in dense stands of macrophytes. This might explain why allelopathic inhibition of algae can often be detected solely under continual influence of allelochemicals and not after single TA additions (Hilt et al. 2006).

\section{TA degradation by isolated bacteria and effects of degradation products on algal growth}

We were able to isolate bacteria strains identified as Pseudomonas growing on TA as the sole carbon source. Several pseudomonads are known to degrade aromatic compounds such as polyphenols (Watanabe et al. 1998, Heinaru et al. 2000) or at least to be indirectly involved in phenol degradation (DeRito et al. 2005). We found close relatives of Pseudomonas species which have been isolated from antibiotic producing waste water (D. Li et al. unpubl. data). Since we did not intend to select for antibiotic-resistant strains nor intended to confirm the antibiotic activity of tannin, we excluded them from the TA degradation experiments. Instead, we used isolates that are closely related to bacteria known for degradation of aromatic compounds (e.g. quinoline; $\mathrm{H}$. Xu et al. unpubl. data) and sulphate oxidation (data not shown).

TA concentrations decreased after incubation with all tested bacterial isolates, which indicates that the isolated bacteria were able to degrade aromatic compounds and thereby reduce inhibitory effects on Desmodesmus armatus. Besides microbial TA alteration, photochemical effects (Espeland \& Wetzel 2001) cannot be excluded but should have been the same in all treatments. Varying effects of TA on phytoplankton sensitivity to allelochemical substances consequently can be assigned to bacterial interactions that either lead to less toxic TA degradation products or improved nutrient allocation from dissociated TA-enzyme complexes. This resulted in the observed beneficial consequences for phytoplankton growth.

\section{CONCLUSIONS}

Allelopathic substances are exposed to a number of abiotic and biotic factors that potentially influence their effects on target organisms. Our study demonstrates that pelagic bacteria in the water column and bacteria attached to phytoplankton have the potential to modify the allelopathic activity on phytoplankton by using hydrolysable polyphenols as substrates. Bacterial degradation of allelochemicals either by a complex bacterial community or specific bacteria isolates reduced the inhibitory effects on the tested phytoplankton. Hence, besides other factors influencing the sensitivity of phytoplankton to allelochemicals, such as seasonal and spatial variations in allelochemical concentration (Bauer et al. 2009), bacteria-mediated effects on algal sensitivity to allelochemicals should also be taken into account. The variability in sensitivity to allelochemicals (when tested in lab experiments using xenic phytoplankton with variable BCC) mainly depends on interactions with the (pre-)conditioned microbial community. Therefore, allelopathy sensitivity tests with undefined bacteria in algal cultures will lead to a misinterpretation of species-specific differences when neglecting the variability in structure and function of bacteria in the test system. Future investigations on in situ sensitivity of phytoplankton to allelochemicals and possible implications for interactions within the ecosystem should thus include potential interactions with bacteria.

Acknowledgements. This study was supported by a national grant of Berlin (NaföG, Nachwuchsförderprogramm, Berlin, Germany) and by a grant of the DFG (GR1540/8-2). We are thankful to T. Hintze, R. Hölzel and M. Klomsdorff (partly financed by the Landesjugendring Brandenburg Trägerwerk) 
for technical assistance. The help of I. Salka, K. HutalleSchmelzer, C. Koppe, C. Dziallas and M. Degebrodt during molecular biological analysis is much appreciated. We thank T. Shatwell for linguistic improvement.

\section{LITERATURE CITED}

Abreu PC, Rörig LR, Garcia V, Odebrecht C, Biddanda B (2003) Decoupling between bacteria and the surf-zone diatom Asterionellopsis glacialis at Cassino Beach, Brazil. Aquat Microb Ecol 32:219-228

Allgaier M, Grossart HP (2006) Seasonal dynamics and phylogenetic diversity of free-living and particle-associated bacterial communities in four lakes in northeastern Germany. Aquat Microb Ecol 45:115-128

Babica P, Ludek B, Marsalek B (2005) Removal of microcystins in phototrophic biofilms. Environ Sci Pollut Res 12: 369-374

Bajaj M, Gallert C, Winter J (2008) Effect of co-substrates on aerobic phenol degradation by acclimatized enrichment cultures. Eng Life Sci 8(2):125-131

Baptist F, Zinger L, Clement JC, Gallet C and others (2008) Tannin impacts on microbial diversity and the functioning of alpine soils: a multidisciplinary approach. Environ Microbiol 10:799-809

Bauer N, Grossart HP, Hilt S (2008) Do bacteria influence the sensitivity of phytoplankton to allelochemicals from submerged macrophytes? Verh Internat Verein Limnol 30: 307-311

Bauer N, Blaschke U, Beutler E, Gross EM, Jenett-Siems K, Siems K, Hilt S (2009) Seasonal and interannual dynamics of polyphenols in Myriophyllum verticillatum and their allelopathic activity on Anabaena variabilis. Aquat Bot 91: 110-116

Box JD (1983) Investigation of the Folin-Ciocalteau phenol reagent for the determination of polyphenolic substances in natural waters. Water Res 17:511-525

Burkert U, Warnecke F, Babenzien D, Zwirnmann E, Pernthaler J (2003) Members of a readily enriched beta-proteobacterial clade are common in surface waters of a humic lake. Appl Environ Microbiol 69:6550-6559

Buzzini P, Arapitsas P, Goretti M, Branda E and others (2008) Antimicrobial and antiviral activity of hydrolysable tannins. Mini Rev Med Chem 8:1179-1187

Chowdhury SP, Kahanna S, Verma SC, Tripathi AK (2004) Molecular diversity of tannic acid degrading bacteria isolated from tannery soil. J Appl Microbiol 97:1210-1219

Cole JJ (1982) Interactions between bacteria and algae in aquatic ecosystems. Annu Rev Ecol Syst 13:291-314

Decho AW (1990) Microbial exopolymer secretions in ocean environments: their role(s) in food webs and marine processes. Oceanogr Mar Biol Annu Rev 28:73-153

> DeRito CM, Pumphrey GM, Madsen EL (2005) Use of fieldbased stable isotope probing to identify adapted populations and track carbon flow through a phenol-degrading soil microbial community. Appl Environ Microbiol 71: 7858-7865

Ervin GN, Wetzel RG (2003) An ecological perspective of allelochemical interference in land-water interface communities. Plant Soil 256:13-28

- Escher BI, Snozzi M, Schwarzenbach RP (1996) Uptake, speciation, and uncoupling activity of substituted phenols in energy transducing membranes. Environ Sci Technol 30: 3071-3079

> Espeland EM, Wetzel RG (2001) Complexation, stabilization, and UV photolysis of extracellular and surface bound glu- cosidase and alkaline phosphatase: implications for biofilm microbiota. Microb Ecol 42:572-585

Freeman C, Lock MA, Marxsen J, Jones SE (1990) Inhibitory effects of high molecular weight dissolved organic matter upon metabolic processes in biofilms from contrasting rivers and streams. Freshw Biol 24:159-166

> Freeman C, Ostle N, Kang H (2001) An enzymic 'latch' on a global carbon store. Nature 409:149

Funatogawa K, Hayashi S, Shimomura H, Yoshida T, Hatano T, Ito H, Hirai Y (2004) Antibacterial activity of hydrolysable tannins derived from medical plants against Helicobacter pylori. Microbiol Immunol 48:251-261

> Gross EM (2003) Allelopathy of aquatic autotrophs. Crit Rev Plant Sci 22:313-339

Gross EM, Meyer H, Schilling G (1996) Release and ecological impact of algicidal hydrolysable polyphenols in Myriophyllum spicatum. Phytochemistry 41:133-138

Grossart HP (1999) Interactions between marine bacteria and axenic diatoms (Cylindrotheca fusiformis, Nitzschia leavis and Thalassiosira weissfloggii) incubated under various conditions in the lab. Aquat Microb Ecol 19:1-11

> Grossart HP, Kiørboe T, Kam T, Ploug H (2003) Bacterial colonization of marine particles: growth and interspecific interactions. Appl Environ Microbiol 69: 3500-3509

Grossart HP, Levold F, Allgaier M, Simon M, Brinkhoff T (2005) Marine diatom species harbour distinct bacterial communities. Environ Microbiol 7:860-873

Grossart HP, Jezbera J, Horňák K, Hutalle K, Buck U, Šimek $\mathrm{K}$ (2008) Abundance and in situ activities of major bacterial groups in Lake Grosse Fuchskuhle (northeastern Germany). Environ Microbiol 10:635-652

He Q, Shi B, Yao K (2006) Interactions of gallotannins with proteins, amino acids, phospholipids and sugars. Food Chem 95:250-254

Heinaru E, Truu J, Stottmeister U, Heinaru A (2000) Three types of phenol and p-cresol catabolism in phenol- and pcresol-degrading bacteria isolated from river water continuously polluted with phenolic compounds. FEMS Microbiol Ecol 31:195-205

> Hilt S (2006) Allelopathic inhibition of epiphytes by submerged macrophytes. Aquat Bot 85:252-256

> Hilt S, Gross EM (2008) Can allelopathically active submerged macrophytes stabilise clear-water states in shallow eutrophic lakes? Basic Appl Ecol 9:422-432

Hilt S, Ghobrial MGN, Gross EM (2006) In situ allelopathic potential of Myriophyllum verticillatum (Haloragaceae) against selected phytoplankton species. J Phycol 42: 1189-1198

Hutalle-Schmelzer K, Zwirnmann E, Krüger A, Grossart HP (2010) Enrichment and cultivation of pelagic bacteria from a humic lake using phenol and humic matter additions. FEMS Microbiol Ecol 72:58-73

Jakob T, Schreiber U, Kirchesch V, Langner U, Wilhelm C (2005) Estimation of chlorophyll content and daily primary production of the major algal groups by means of multiwavelength-excitation PAM chlorophyll fluorometry: performance and methodological limits. Photosynth Res 83: 343-361

Kent AD, Yanarell AC, Rusak JA, Triplett EW, McMahon KD (2007) Synchrony in aquatic microbial community dynamics. ISME J 1:38-47

Körner S, Nicklisch A (2002) Allelopathic growth inhibition of selected phytoplankton species by submerged macrophytes. J Phycol 38:862-871

Loh KC, Wang SJ (1998) Enhancement of biodegradation of phenol and a non growth substrate 4 -chlorophenol by 
medium augmentation with conventional carbon sources. Biodegradation 8:329-338

Müller N, Hempel M, Phillip B, Gross EM (2007) Degradation of gallic acid and hydrolysable polyphenols is constitutively activated by the freshwater plant-associated bacterium Matsuebacter sp. FB25. Aquat Microb Ecol 47: 83-90

Mullin CA (1988) Adaptive relationships of epoxide hydroxylase in herbivorous arthropods. J Chem Ecol 14:1867-1888

Nakai S, Inoue Y, Hosomi M, Murakami A (1999) Growth inhibition of blue-green algae by allelopathic effects of macrophytes. Water Sci Technol 39:47-53

Newton RJ, Kent AD, Triplett EW, McMahon KD (2006) Microbial community dynamics in a humic lake: differential persistence of common freshwater phylotypes. Environ Microbiol 8:956-970

Porter K, Feig YS (1980) The use of DAPI for identification and enumeration of bacteria and blue-green algae. Limnol Oceanogr 13:389-398

Scalbert A (1991) Antimicrobial properties of tannins. Phytochemistry 30:3875-3883

Scheffer M, Hosper SH, Meijer ML, Moss B, Jeppesen E

Editorial responsibility: Karel Šimek,

České Budejovice, Czěch Republic
(1993) Alternative equilibria in shallow lakes. Trends Ecol Evol 8:275-279

Schleheck D, Knepper TP, Fischer K, Cook AM (2004) Mineralization of individual congeners of linear alkylbenzenesulfonate by defined pairs of heterotrophic bacteria. Appl Environ Microbiol 70:4053-4063

Smith AH, Zoetendal E, Macki RI (2005) Bacterial mechanisms to overcome inhibitory effects of dietary tannins. Microb Ecol 50:197-205

Walenciak O, Zwisler W, Gross EM (2002) Influence of Myriophyllum spicatum-derived tannins on gut microbiota of its herbivore Acentria ephemerella. J Chem Ecol 28: 2045-2056

> Watanabe K, Yamamoto S, Hino S, Harayama S (1998) Population dynamics of phenol-degrading bacteria in activated sludge determined by gyrB-targeted quantitative PCR. Appl Environ Microbiol 64:1203-1209

Woo JH, Hwang YO, Kang SG, Lee HS, Cho JC, Kim SJ (2007) Cloning and characterization of three epoxide hydrolases from a marine bacterium, Erythrobacter litoralis HTCC2594. Appl Microbiol Biotechnol 76: 365-375

Submitted: September 7, 2009; Accepted: January 14, 2010 Proofs received from author(s): April 12, 2010 